
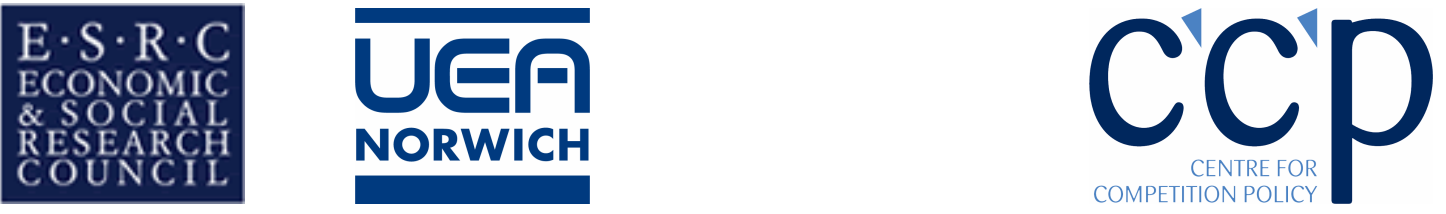

\title{
Revisiting Modernisation: the European Commission, Policy Change and the Reform of EC Competition Policy
}

\author{
by \\ Hussein Kassim \\ School of Political, Social and International Studies, and Centre for \\ Competition Policy, University of East Anglia \\ $\&$ \\ Kathryn Wright \\ Centre for Competition Policy, University of East Anglia
}

\section{CCP Working Paper 07-19}

Work in progress. Please contact authors for the latest version.

\begin{abstract}
The modernisation of EC antitrust rules timed to coincide with the 2004 enlargement of the European Union is widely recognised as an historic and revolutionary reform. According to the dominant view that has emerged in both law and political science, the change is to be explained in terms of the interest and ability of the European Commission to engineer a reform that, behind the guise of decentralisation to national authorities, has in practice extended its power and influence over the control of anti-competitive agreements. Drawing on original research, this paper contests the conventional wisdom and the image of the Commission as an imperialistic actor that underlines it. It argues that such a view dramatically overstates the Commission's power and that a more sophisticated explanation is required. First, the Commission was motivated more by changes in the thinking within an epistemic community of competition practitioners and lawyers than by an impulse to expand its authority. Second, contrary to the monolithic conception of the Commission on which the dominant view depends, the Commission was internally differentiated and the development of its reform proposals the product of internal negotiation and conflict, rather than the expression of an inner drive to expansionism. Third, scrutiny reveals the Commission to be a constrained organisation, rather than a body able to re-write competition law autonomously.
\end{abstract}

August 2007 
JEL Classification Codes: $\mathrm{P} 48$

Keywords: Modernisation, reform, European Commission, competition policy

Acknowledgements: The authors would like to express their thanks to officials from the European Commission and national authorities who very kindly agreed to grant non-attributable interviews as part of the research for the project on which this paper is based. We also thank participants of the ESRC Centre for Competition Policy research seminar and the competition policy workshop at Exeter University, as well as Lindsay Stirton, for their valuable comments on earlier versions of this paper. The support of the Economic and Social Research Council is also gratefully acknowledged.

\section{Contact details:}

Hussein Kassim, Political Science Mentor, Centre for Competition Policy, University of East Anglia, Norwich NR4 7TJ, UK

hhkassim@hotmail.com

Kathryn Wright, Research Associate and PhD Candidate, Centre for Competition Policy, University of East Anglia, Norwich NR4 7TJ, UK kathryn.wright@uea.ac.uk 
The image of the European Commission as a self-interested, if not imperialistic, actor, motivated by a desire to maximise its influence and seeking ever to expand its power, remains widely influential in European integration scholarship. A premise of many analyses of the inter-institutional politics of the European Union, it also informs accounts of policy making and policy change, including those that address the recent modernisation of the European Community's antitrust rules (see Riley 2003a, 2003b, Wilks 2005a), justly and widely regarded as a 'revolutionary' and 'historic' reform. ${ }^{1}$ The emerging conventional wisdom in both law and political science on this key competition policy reform attributes a central role to the European Commission. It contends that the Commission seized the opportunity of the impending enlargement to engineer a reform that enabled it to relieve DG Competition of its heavy workload of mundane casework by a major transfer of responsibilities to competition authorities in the member states, while reserving the most important and prestigious activities for itself. According to this view, moreover, the Commission managed under the guise of radical decentralisation to maintain, and even to strengthen, its central position and overall control of antitrust.

This paper contests this view. It argues first, drawing on original research conducted by the authors, ${ }^{2}$ that the conventional interpretation of this historic modernisation is flawed in several important respects. Its preoccupation with the Commission and its assumptions about the Commission's motivations leads it to overstate dramatically the Commission's power and influence over developments relating to the reform, and to offer a misleading representation of the reform process. In particular, the narrow focus on the Commission's supposed power-maximising ambitions leads to a disregard for other factors that may have been important in prompting the Commission to initiate reform. In addition, the image it portrays of the Commission as a monolithic actor leads it to overlook potentially consequential internal decision-making

\footnotetext{
${ }^{1}$ Claus-Dieter Ehlermann, a former Director General of DG IV, described the White Paper containing the proposals which largely formed the basis of the reform as: 'the most important policy paper the commission has ever published ... It suggests a legal and cultural revolution in proposing the fundamental reorganization of existing responsibilities between the Commission, national authorities and national courts' (2000: 537). See also Gerber (2001: 126-128).

${ }^{2}$ Lindsay Stirton, Law School and ESRC CCP, UEA, is a third member of the research team.
} 
processes within the organisation. Other theoretical approaches that share the same assumptions are equally vulnerable to this charge.

The paper's second argument, based on a detailed examination of the reform process, is that a more sophisticated approach needs to be taken when explaining the Commission's role in policy development and policy change. While not denying that the reform benefited the Commission in important respects, it argues that self-interest may not be the only motivation for policy change initiatives and that, at the very least, attention needs to be paid to ideas and institutions. In the case of modernisation, as the Commission was not so much moved to action due to any imperialist impulse, but due to changing norms and understandings within the competition law and policy community - an epistemic community ${ }^{3}$ - about how antitrust rules should best be designed and administered. In other words, the stimulus to reform came not from a calculation on the Commission's part about how to maximise its material interests, but from criticism from within a community of experts to which it belonged. Modernisation also illustrates the importance of insights from the new institutionalism in at least two ways. The first concerns the value of opening the 'black box' to reveal, and then to explore, the intraorganisational processes of the Commission as an internally differentiated institution. The second relates to the power of the Commission within the EU policy process. Rather than an ability to dictate policy outcomes, scrutiny reveals a constrained institution, forced to compromise and to seek consensus. The Commission was not empowered to re-write competition law autonomously.

The discussion that follows is organised into three parts. The first section offers a brief description of the modernisation package and the measures it contained. It considers the key features of the regime that it replaced, and identifies the main changes implemented as part of the reform and discusses their significance. The second section considers the dominant view of the reform process as it has emerged in law and political science. It highlights the

\footnotetext{
${ }^{3}$ See Haas (1992) for the original development of this term; see van Warden and Drahos (2002) for an application of the concept to the competition law and policy community. Wilks (2005a: 431) refers to 'a legal epistemic community' and (2005b: 113) writes of 'a law-dominated epistemic community'.
} 
four key propositions on which these explanations rest. The dominant perspective on modernisation is critically examined in the third part of the paper. The four propositions are discussed in turn. Key aspects of the reform process are recounted and explored in an account that draws on original research conducted by the authors that challenges the conventional view.

\section{AN HISTORIC MODERNISATION}

The package of reforms adopted between December 2002 and April 2004 brought about a genuinely historic change in the European Community's antitrust regime. ${ }^{4}$ This is an area where the Community was granted farreaching competencies under the founding treaties and where considerable power had subsequently been delegated to the Commission. The modernisation introduced wide-ranging changes in a system that had operated for over forty years.

\section{The status quo ante}

The Commission occupied a central position in the antitrust regime that existed until Council Regulation 1/2003 entered into effect on 1 May 2004, timed to coincide with the accession of the ten new member states from Central and Eastern Europe. It had been given considerable powers in applying and enforcing treaty competition rules in this area. The first clause of Article 81 [ex Article 85] EC prohibits all agreements and concerted practices between firms that affect trade between the member states and that 'have as their object or effect the prevention, restriction or distortion of competition within the common market'. However, Article 81(3) permits exemptions from the prohibition with four cumulative conditions - two positive and two negative - where an agreement 'contributes to improving the production or distribution of goods or to promoting technical or economic progress allowing consumers a fair share of the benefit and which does not (a) impose on the undertakings concerned restrictions which are not indispensable to the attainment of these objectives [proportionality]; (b) afford such undertakings the possibility of eliminating competition in respect of a substantial part of the products in

\footnotetext{
${ }^{4}$ For a list of the measures that comprised the package, see Appendix. For useful commentary and analyses, see Goyder (2003), Wilks (2005a, 2005b), Simanska (2005), Pijetlovic (2004), McGowan (2005), Venit (2003).
} 
question [market power]. These provisions had been given effect by Council Regulation 17, the cornerstone of the status quo ante and the original implementing measure of the treaty's rules concerning antitrust, adopted in 1962.

The regulation required that companies notified the Commission of all new commercial agreements that may affect trade between member states. It entrusted the Commission with sole power to grant exemptions to companies from the general prohibition. ${ }^{5}$ It also gave the Commission extensive procedural powers, enabling it to act independently of the member states in the exercise of its responsibilities in the area of antitrust (see Goyder 2003; Cini and McGowan 1998). This delegation of powers to the Commission, which gave it alone the authority to give clearance to agreements, and the requirement on companies to notify, placed the Commission firmly at the centre of the Community's antitrust regime.

The modernisation package replaced Council Regulation 17 - a move that had symbolic, as well as substantive, importance. Among the changes it brought, the two most radical were the abolition of the notification system and the decentralisation of the application of Article 81. As a consequence of the first, the obligation on companies to notify the Commission of agreements that may damage competition was abolished. Companies are now responsible for making their own assessment of the legality of the agreements into which they enter, subject to the scrutiny of NCAs and national courts. The second gave national competition authorities and courts the authority to grant exemptions under Article 81 (3), thus ending the Commission's monopoly.

Regulation 1/2003, the main element of the modernisation package, was accompanied by a number of measures designed to ensure the coherent application of the Community's antitrust rules across the Union, following the abolition of the Commission's monopoly. A European Competition Network (ECN), comprising the Commission and national competition authorities

\footnotetext{
${ }^{5}$ As Wilks (2005a: 433) notes, Regulation 17 borrowed from German law where all agreements were considered illegal until notified and explicitly approved.
} 
(NCAs) from all EU member states, was created as the main mechanism for ensuring the enforcement of these rules. ${ }^{6}$ The members of the network are charged with exchanging information about cases and information. It was also expected that the network, a form of 'soft law', which member states have declared they will respect, would provide 'a forum for discussion and cooperation in the application and enforcement of EC competition policy' (Commission 2004, para 1). The Network allocates cases according to the 'best placed to act' competition authority. This means that the NCA must observe actual or foreseeable effects of the practice at issue on its territory; the authority is capable of bringing the infringement to an end; and that it can gather the evidence needed to prove the infringement. ${ }^{7}$ In most cases, the authority that first receives the complaint or initiates an investigation will be best placed to act, ${ }^{8}$ but cases can be opened and investigated at the same time by several authorities, and in cases where more than three member states are affected, the Commission is most likely to be in a position to handle the case. Three other features of the network are also important: NCAs cannot contradict or overrule Commission decisions, and when Commission initiates proceedings, national authorities are relieved of their competence; national authorities are obliged to apply Community law in any case where trade between member states is affected, and member states can only apply national laws that are stricter than Community rules in the case of prohibition of unilateral conduct.

The Commission gave several reasons for the reform. ${ }^{9}$ First, with the development and spread of a culture of competition across Europe, the Commission's monopoly was no longer necessary. With the emergence of widespread competition expertise, it was no longer the sole guardian of competition within the Union. Second, impending enlargement threatened to increase dramatically the number of cases notified to the Commission. Third, lifting the notification requirement on companies would relieve business of an

\footnotetext{
${ }^{6}$ For discussions of the ECN, see Maher (2005) and Wilks (2005b).

${ }^{7}$ Network Notice, para 8. Paragraphs 8-15 of the Network Notice give illustrative examples.

${ }^{8} \mathrm{NCAs}$ are obliged to inform the Commission before or without delay after commencing the first formal investigative procedure: Art 11(3) Reg 1/2003.

9 The deficiencies of the existing system were well-known and widely recognised. The title of a book on the subject by Neven et al (1998) - trawling for minnows - captures one of the aspects in which Community rules were problematic.
} 
unnecessary burden and, because they would no longer have to wait for comfort letters, the status of which was somewhat uncertain, would improve predictability. Fourth, decentralisation and the abolition of notification would ease the Commission's workload and enable it to focus on hardcore cartels.

\section{EXPLAINING MODERNISATION I: THE DOMINANT VIEW}

An emerging conventional wisdom in both law and political science interprets these reforms as not so much empowering national competition authorities, but as a successful attempt on the part of the European Commission to strengthen and extend its powers in regulating competition in the Union, while presenting the package as an exercise in decentralisation.

\section{Modernisation: a triumph for the Commission}

The principal advocate of this view in the law literature is Alan Riley (2003a, 2003b). Reflecting on the modernisation package, he concludes that:

'[T] he Commission has orchestrated a political masterstroke. It has given the impression of radical reform to the member states by abolishing the notification procedure and offered decentralisation provisions largely based on the existing and under-used NCA and National Courts Notices, which in no way undermine its central role in the development of EC competition policy or enforcement of EC competition law. DG Competition has in fact managed to centralise European competition law even more than under Regulation 17 in its Rue Joseph II headquarters' (2003a: 604)

Riley points to four features of the new Regulation in support of his contention that 'it is the Commission who is the principal if not sole beneficiary of the new regulation' (2003b: para. 6.0).

First, he contends that the abolition of the notification system 'is not the radical step it first appears ... [but] merely the removal of an already irrelevant procedure, with marginal impact on the operation of the EC competition rules' (2003a: 604). He argues second that the Commission has, by requiring under Article 3 that EU law should be applied by all NCAs to agreements that fall within their remit that meet the interstate trade test, 'ousted the operation of national competition law from most restrictive practices cases and thereby 
ensured direct supervision over such cases'. The effect is to substitute European law for national law. Third, he asserts that the Commission has also under Article 3 extended its powers beyond those that it enjoyed under Art 9(3) of Regulation 17. It has wider powers of investigation, can impose heavier fines, and can negotiate conditional arrangements with companies. Fourth, he claims that the ECN is an instrument of Commission control over NCAs rather than a partnership arrangement with them. NCAs have no escape from Community jurisdiction, he argues, since the Commission can potentially take over any case. All decisions are effectively taken in the shadow of DG COMP.

Stephen Wilks has advanced a similar argument in the political science literature. Like Riley, whom he cites approvingly, Wilks argues that the reform represents an 'imperialist move by the Commission to centralize competition enforcement and to consolidate control over increasingly assertive group of NCAs' (Wilks 2005a: 446)', contending that the 'Commission has executed strategic coup in reinforcing power of DG Comp, marginalizing national laws and centralizing control of application of European law' (2005a: 449-50). He thus shares the same views about the Commission's motivations in bringing the reform about, but is even more explicit in isolating the impetus behind the reform. According to Wilks, the Commission was 'not reacting to any groundswell of public protest ... not under majoritarian pressure, but chose to reform in pursuit of its own agenda' (2005a: 436).

Moreover, Wilks sees the creation of ECN as part of 'an extraordinary coup' (2005a: 437) by the Commission. Together DG COMP and the new Network represent 'the equivalent of a transnational agency that has gone beyond the power of the member states to control' (ibid). Yet, 'the member states have not made this grant of authority voluntarily or even consciously. The Commission has engineered a coup, which it has concealed behind a façade of administrative functionality and legal necessity' (ibid). Drawing a comparison with EMU, Wilks suggests that the modernisation reforms have created, in the competition field, the functional equivalent of the European Central Bank with its network of the European System of Central Banks' 
(2005a: 438). He argues that the Commission's 'audacious coup' (2005a: 438) can be explained in terms of the agent's ability to exploit 'its expertise, information asymmetries, and established position to create an additional grant of delegation' (2005a: 439), a sociological institutionalist interpretation, 'which emphasizes the Commission's own motives and independent goals' (2005a: 449) and, following Majone (2001), that it has increased its power from that of a mere agent to that of a trustee.

Both authors highlight potential risks and difficulties in the new regime, particularly with respect to the ECN, that may lead to future problems that may destabilise the new system by threatening its coherence or producing fragmentation. Wilks, moreover, offers two possible readings of modernisation - the first, that the reform represents a genuine decentralisation of authority; the second, that it enhances the Commission's authority - but opts unequivocally for the second: 'that of dominance' Wilks (2005a: 432).

\section{The dominant view: a critical analysis}

The assumptions underlying these two analyses are similar and important. The first two are relatively explicit; namely that, in contemplating policy change or policy reform, the Commission is driven fundamentally by a concern to extend own authority and power (proposition 1) and that it will exploit, and even create, opportunities in its pursuit of these goals (proposition 2). A third is less explicit, but nevertheless discernable. This is the proposition that the Commission has the ability to impose, or more weakly, engineer the negotiation of a settlement that advances its interests thus defined (proposition 3). The analyses are also noteworthy for what neither says explicitly, but what is evidently an implicit assumption that informs the arguments of both; namely, that the Commission is a monolithic actor with a single set of preferences (proposition 4). Both treatments are cast in terms of interests that attributed to the Commission - the terms 'Commission' and 'DG Comp' are used interchangeably - and their attribution is not problematised. In neither account is there any reference to internal discussions within the Commission or to the possibility that there were competing perspectives within 
the organisation - between or within relevant units within DG COMP or elsewhere, between DG COMP and the Legal Service, or within the College or even that there was an internal process of decision making. This is particularly surprising, and at the very least a potentially serious omission, not only given the landmark importance of the reform, but in view of the uncertainties that may have been felt by some Commission officials about, on the one hand, the surrender of its historic and symbolically significant monopoly and, on the other, the 'leap in the dark' entailed by the creation of the ECN.

All four propositions are in fact problematic. All four need to be carefully interrogated when employed in a research programme and alternative hypotheses tested. The first, concerning the driver of Commission action, is problematic, because it discounts the possibility that the Commission may be motivated by other factors or influences. It discounts, for example, the possibility that the Commission may be concerned principally to ensure that the provisions of the Treaty are respected or that the general interests of the European Union are advanced, or that it has more concerns that are sectoror issue-specific, such as the need to respond to a crisis or to act where a legislative instrument is ineffective. It also excludes instances where the original impetus comes from outside the Commission - where, for example, another EU institution or a member state requests action - or where it is part of a community populated by other specialist or expert bodies. A further problem is that the desire to expand its competences is a vague and general proposition that does not necessarily generate specific hypotheses or assist in accounting for why the Commission selected one competence-maximising option over another.

Many of the difficulties that arise in relation to proposition 1 also apply to proposition 2. However, a more specific problem concerning the latter relates to the way in which possibilities for policy reform emerge. Proposition 2 suggests that windows of opportunity are engineered by the Commission, but this discounts the possibility that other factors or other actors may create circumstances where Commission action is called for or where it comes under 
pressure to act. In other words, there may be occasions where the Commission is innocent, as it were, of bringing about a situation where action on its part is necessary. For example, it may be that the DG in question is part of an expert community in which its procedures and practices come under scrutiny and criticism and that this outside pressure, in combination with a sense of institutional pride, rather than a desire to expand its power, provides the stimulus to reform. It may even be that the Commission does use such opportunities presented to extend its empire, but this is a thesis that needs to be tested rather than assumed and if it were confirmed would not establish that a desire to increase its powers explains why the reform was embarked upon.

Proposition 3 is perhaps the most self-evidently problematic of the four propositions, since there are few areas where the Commission can act unilaterally and dictate outcomes that are favourable to it (Bulmer 1994). The Commission is, of course, an important and influential actor as agenda-setter, policy manager, ring-holder, and policy enforcer, with significant resources, but the design of the EU policy process makes it dependent on other actors and institutions. Indeed, even in those few (regulatory) areas where the Commission does have the power to act independently, as, for example, in some areas of competition policy, it generally exercises its prerogatives with circumspection, and though it can use its powers to compel the member states to take action that they would not choose to take if not compelled so to do (Schmidt 2002), the examples of where it has done so are few indeed (Schmidt 2002, Kassim and Stevens forthcoming). In most areas covered by the Treaty, no single actor has the ability to determine the final policy decision. Both formal rules and informal understandings enforce inter-institutional interdependence. Legislative power is shared between the Commission, the European Parliament and the Council of Ministers, and the executive function in its various forms between the Commission and the European Council (leadership), the Commission and member governments (comitology), and the Commission and national administrations (implementation and enforcement). 
There are three difficulties with proposition 4, arising from the fact that it effectively 'black boxes' the Commission. ${ }^{10}$ The first is that empirical work tends to suggest that the Commission is less a monolith than a 'multiorganization' (Cram 1994) or even a multiorganisation of multiorganisations. The second relates to processes. Proposition 4 directs attention towards the Commission's output, but disregards how it arrives at a decision or develops its preferences. ${ }^{11}$ However, its internal processes may hold important clues as to why a particular position is adopted. In other words, it may be the case that the stance that is struck by the Commission may have more to do with an internal power balance and the way that its procedures distribute power within the organisation than a material interest that can simply be 'read off' from its position within the political. The third concerns the terms of internal debate and the possibility of conflict within the Commission. It may be the case that administrative units or individuals across the Commission and at different levels do not share the same view about the interests of the institution or about what course of action is desirable. In such circumstances, how the Commission formulates its position is important and becomes an important part of the narrative about how reform was achieved.

Although the discussion below will focus on the difficulties associated with these propositions in relation to modernisation, it has a more general significance, since these propositions are widely used in EU scholarship in the analysis of policy development and policy reform. ${ }^{12}$ In terms of the model of bureaucratic self-interest on which they rely, moreover, they have obvious affinities with the classic rational choice literature, notably, Niskaken's budgetmaximisation theory of bureaucratic motivation (Niskanen 1971) and the more recent sophistications of work in this tradition, most notably, Dunleavy's bureau-shaping model (Dunleavy 1991). Whereas the former had argued that bureaucrats seek to maximise the size of their bureau's budgets, the latter contends that budgets may be less important to bureaucrats than

\footnotetext{
${ }^{10}$ The term is used by Beach (2003) albeit in another context.

${ }^{11}$ For discussion of the importance of opening the black box in relation to the Commission's participation in the Convention on the Future of Europe and the Future of Europe debate more broadly, see Kassim and Dimitrakopoulos (2006), Kassim and Dimitrakopoulos (forthcoming 2007).

${ }^{12}$ This image is widespread in the EU literature (see, e.g. Hix 1999, 2005), though does not go unchallenged (Cram 1994).
} 
responsibility for prestigious work. During periods of reform, bureaucrats are likely to promote an agenda aimed at eliminating routine tasks to enable them to concentrate on more heroic activities. ${ }^{13}$

\section{EXPLAINING MODERNISATION II: BEYOND BUREAUCRATIC SELF- INTEREST}

The findings of a detailed investigation of the modernisation of the European Community's antitrust rules pose a serious challenge to the conventional account of that reform and confirm that the four propositions identified above are indeed problematic. The following section argues that the reform cannot be explained in terms of bureaucratic self-interest and power, but necessarily must factor in the importance of ideas and institutional and organisational factors. The section that follows thereafter supports this alternative account. It highlights aspects of the reform process that are disregarded or misrepresented by exponents of the dominant view.

\section{The modernisation of the antitrust rules: bringing ideas and institutions back in}

The emerging conventional wisdom seeks to account for the modernisation by casting the Commission as a self-interested and powerful bureaucracy, motivated by a concern to extend its own remit and with the ability so to do. An alternative account departs from the narrowly materialist premises of this approach and highlights the importance of ideational, institutional and organisational factors.

First, the account challenges the rather solipsistic image of a self-interest and empire-building Commission that informs the dominant view. It emphasizes the importance of ideas by stressing the influence of technical expertise within a community of specialists. It presents the Commission, or more specifically, officials from DG COMP, as members of an international expert community of lawyers and economists specialising in competition policy. This is a community that is governed by certain shared norms and understandings, which reasons in a particular way and which upholds similar values (see Van

\footnotetext{
${ }^{13}$ This thesis has an intuitive appeal in case of modernisation, since it could read reform as delivering to Commission more glamorous cases, while leaving NCAs to perform the mundane tasks.
} 
Waarden and Drahos 2002). Its leading members meet regularly at certain points in the calendar year - notably, at Fordham and at the EUI in Florence to reflect upon issues of common interest, such as changing practices and procedures. Certain institutions and individuals exercise considerable influence within this community. Discussions and exchanges within this group of peers may, because norms are shared and common challenges confronted, be more important or consequential for officials from competition authorities than the views of their colleagues from other departments in their own organisations or governments. Not only does it envisage an alternative source of the impetus for policy change (contra proposition 2), but it suggests that Commission officials may be driven less by a concern to increase the power of their organisation and more by the desire to adopt best professional practice or by institutional pride (contra proposition 1).

The alternative account, moreover, underlines the importance of viewing the Commission not as an actor that is able to dictate the outcomes of a decisionmaking procedure that involves multiple actors (contra proposition 3 ), but as a body that operates within a complex institutional setting that imposes requirements and constraints. Its experience of working within such a setting, as well as its predictions about how others will act, influences the content of its proposals, which are based on a calculation of what is negotiable. How power is distributed between actors, meanwhile, as well as the positions that they adopt, will affect how much of the Commission's original proposal is retained in the decision that is finally adopted. In the case under consideration, the European Parliament is involved only through the consultation procedure, while the Council acts by qualified majority, although, as in many areas and particular in view of the importance of the provision concerned, there is a preference for seeking consensus where member states, especially a large and powerful one with a strong grievance (see below), find themselves isolated.

Finally, the Commission proves not, contra proposition 4, to be a monolithic organisation, but to be internally differentiated. Indeed, the concern to keep reform possibilities as broad as possible led those responsible in DG COMP 
for developing the reform proposals to avoid general discussion within the Directorate-General, as they assumed that opinion would be strongly opposed to any decision to give up the Commission's monopoly in respect of Article 81 (3). Not only were there differing opinions within DG COMP, however, but the Competition Commissioner and his cabinet took a more radical position than his services. In other words, there were both horizontal and vertical lines of differentiation within the Commission.

\section{The modernisation of the antitrust rules: an alternative perspective}

Space does not permit an exhaustive rehearsal of the case study. However, a focus on four key aspects of the reform process and its outcome is sufficient to demonstrate the importance of the ideational, institutional and organisational factors highlighted above and to reveal the shortcomings of the conventional wisdom.

\section{An external impetus to reform}

According to the dominant account, the Commission moved to initiate reform not in reaction to public protest or pressure from the member states, but in order to extend its own power (proposition 1) and to prosecute its own agenda (proposition 2). While it is true that the reform was not begun in order to meet the demands of European citizens or because national governments had expressed dissatisfaction with the existing system, closer investigation reveals that the original impetus came from outside the Commission rather than from within it. Although the Commission was aware of the failings of the status quo ante, which are well documented, what led to the decision to reflect on ways in which the system could be improved and reformed was less the threat posed by the coming enlargement to an already unworkable system - indeed, the definitive decision about the timing of the entry of states of central and eastern Europe had not been taken at the time - but more criticism levelled by legal specialists at the Community system that began at the Fordham Conference in the autumn of 1996.

The fact that historically few countries had powerful competition authorities or developed competition regimes - Germany was an exception - has been 
viewed by the Commission as an important reason for retaining its powers, including its monopoly over the grant of exemptions for anti-competitive agreements. However, this situation changed significantly in the 1990 s during which period an increasing number of member states introduced new competition regimes or reformed existing ones. Many were modelled on the EC system or were similar to it in design, but others developed different procedures, reflecting different priorities, principles and approaches. The growing number of national competition authorities not only significantly expanded the community of competition specialists, but it had the consequence that the Commission was no longer one among a small number of competition authorities, nor necessarily a pacesetter. Indeed, within this expanding community, competition authorities from a number of states viewed the EC system as problematic. At the 1996 Fordham Conference, the Italian and Irish competition authorities made presentations that were critical of the Community system. ${ }^{14}$ At this regular prestigious transatlantic gathering, Barry Hawk, a leading authority on competition law, contended that Article 81 (3) was too wide, that the Community system of antitrust control was too bureaucratic and too formalistic, and that it did not take real decisions or uncover the main anti-competitive cases. These criticisms were repeated at the annual meeting in Florence, hosted by Claus-Dieter Ehlermann, a former Director General of DG Competition.

In response to these criticisms, a group was set up by a senior official within DG IV in early 1997 to reflect on how EU competition law might be modernised. This was the group that produced the White Paper on which Council Regulation 1/2003 was very largely based. Indeed, the only major element in the regulation that did not feature in the modernisation group's proposal was the provision (Article 3), removing the possibility of applying national law. Significantly, this group, described by officials as the 'single driving force' of reform, met in secret, largely because it was feared that the

\footnotetext{
${ }^{14}$ Patrick Massey (1996) 'Reform of EC competition law: substance, procedure, institutions', and Alberto Pera and Mario Todino (1996), 'Enforcement of EC competition rules: need for a reform?' The Community rules came under further scrutiny in 1997 (see Mario Siragusa, 'Rethinking Art 85: problems and challenges in the design and enforcement of the EC competition rules' and 1998, where the roundtable topic of discussion was 'EC competition system - proposals for reform'.
} 
reform possibilities it was likely to entertain would meet considerable opposition from within DG IV, where the Article 81(3) monopoly was regarded as an article of faith. Its membership of ten to twelve officials were handpicked by the senior official from DG IV and the Commission's Legal Service on the basis not only of their expertise, but also their energy - the group included a number of young high fliers - and had no formal contact with the hierarchy within DG IV while it drew up the proposals that would ultimately form the basis of the White Paper.

Thus, the reform did not originate internally within a bureaucracy intent on expanding its own power and authority. The impetus came from outside the Commission from a community of experts that, from a perspective informed by experience, had highlighted deficiencies with the Community system. The motivation arose less from an imperialist impulse than a concern to update procedures and practices that were outdated and out-of-step with contemporary approaches, and recognition on the part of technical experts that the mission of their organisation could be more effectively pursued.

\section{An internally differentiated institution}

The conventional wisdom on the modernisation of the Community's antitrust rules says little about internal processes within the Commission. The tendency is to 'black box' the Commission and to attribute to it a single interest (proposition 4), thereby ignoring the possibility that internal interactions within the organisation may have been consequential. In fact, as described above, the decision to create a modernisation group that would meet in secret was taken expressly because it was believed that, because notification was regarded as 'extremely Commission friendly' (interview), it would not be possible to conduct a wide-ranging review that could produce a recommendation that notification should be brought to an end, if the normal procedures were pursued and the relevant administrative unit within DG IV charged with responsibility for bringing forward a proposal.

It was not only intra-departmental factors, moreover, that played a part in the shaping of the reform initiative. There were a number of important junctures 
where the Competition Commissioner and the members of his cabinet, who favoured the more radical option of abolition, confronted the more conservative viewpoint that was widespread within the services. Thus, a vertical dynamic was also relevant to the reform process.

\section{A negotiated agreement}

The dominant view assumes that the Commission was unproblematically able to secure the outcome that it favoured (proposition 4). However, this is a somewhat bold claim given the diversity of approaches to competition policy among the member states and the fact that the Commission had to navigate its way through negotiations with the Council.

With respect to the first, it is useful to distinguish between three main positions: enthusiastic modernizers, conservative upholders of the notification regime, and moderates. The UK and Ireland could be counted among the first camp, Germany represented the second, and France and Spain featured in the third. Germany's opposition to the Commission's proposal, a key feature of the negotiations, was significant not only because Germany was a big state, but it had the oldest developed national competition regime in Europe and its system, similar in important respects to the Community regime, was indeed the model for it. As the negotiations developed, Germany's isolation became clearer, as the BKA argued that notification was implied by the Treaty (Council Regulation 1/2003, Article 2). Although only a qualified majority was required formally, the view that the importance of the decision was such that unanimity was desirable was widespread. Ultimately, unanimity was indeed secured, but only because the German delegation agreed to give its approval to the package as the result of last minute political intervention (interviews).

Moreover, there were several areas of contention where negotiations or other interventions led to significant changes or compromise to the Commission's original proposals. The main issues were as follows [details to be added]:

- Art 3: exclusive competence for intra-Community trade applied to both Arts 81 and 82 , and other exceptions, including mergers 
(and fair trading and environmental protection): the Commission conceded in both instances

- Art 4: double jeopardy

- Art 11: NCA obligation to inform [from 'consult' in the original draft] Commission before adopt a position

- Art 2: burden of proof

- Art 16: codifies ECJ's ruling in Masterfoods

The fact that significant changes were made to the text during the course of its negotiation reveals that, though able to influence the outcome, the Commission was certainly not able to dictate it. The footnotes of national positions in the working documents kept by the Council Secretariat, moreover, run to 61 pages - an indication that the final outcome was by no means predetermined.

\section{A leap in the dark or an extension of Commission imperium?}

A final aspect of the modernisation also challenges the view that the Commission can or does successfully engineer outcomes that are favourable to it (proposition 4). The dominant view makes this assertion, but only because it offers a best-case reading of the modernisation package and overlooks the risks that inhere in the design of the network. Rather than a failsafe instrument for guaranteeing or extending the Commission's power, the creation of the ECN carries a number of risks and poses a number of as yet unanswered questions.

Although networks have proliferated as an instrument of regulation at the EU level, it is by no means clear that they have demonstrated their efficacy (see Coen and Thatcher forthcoming 2008, Egeberg 2006). Moreover, there are few that exercise such far-reaching power in an area of such central importance as the ECN. There are, in addition, concerns about the impact that different levels of resource (expertise and experience, as well as human resources) between NCAs will have on the functioning of the network, about whether NCAs from the large member states will, having achieved significant autonomy in recent years from government and parent ministries, be prepared to cooperate with their counterparts and the Commission, and about whether 
NCAs in the smaller member states will be effective enough. There are also concerns about diversity between national laws, particularly those provisions concerning leniency, fines and prison sentences (Fingleton n.d), and the threat posed to the uniform application of Community competition law across the territory of the Union. Anxiety from a different direction concerns whether the ECN will stem innovation, given that that the national level has proved a source of creativity and promoted novel approaches (Fingleton n.d.). Furthermore, whether national courts will interpret Community law similarly is a serious cause for concern.

In short, the dominant view portrays the modernisation of the $\mathrm{EC}$ antitrust regime as a victory for the Commission. DG COMP has effectively centralised power and ensured, through the design of the ECN, the perpetuation of its control. How the ECN performs in practice, however, is of course an empirical matter, and may be a far riskier enterprise than the emerging conventional wisdom allows.

\section{CONCLUSION}

As a genuinely revolutionary transformation, the modernisation of the Community antitrust regime has, unsurprisingly, attracted considerable attention. However, the dominant interpretation that has emerged in both law and political science is seriously flawed. The view that the reform can be explained in terms of action on the part of an opportunistic Commission, driven by a concern continuously to expand its power, and ready and able to engineer an opportunity to enhance and strengthen its position, is problematic. An alternative perspective, supported by fieldwork conducted by the authors, suggests that impetus for the reform came not from within the Commission, but from critical opinion from other members of an epistemic community of which the Commission is a part, that the Commission was not able to impose its preferences on other EU actors, but had to negotiate and compromise as always in EU decision-making, and that the Commission was not of one mind in bringing forward its proposals. Furthermore, the ECN is not a fail-safe instrument to perpetuate Commission power and control, but an experimental and potentially risky 'leap in the dark'. 
Moreover, the findings of the case study have relevance beyond this particular area of policy or this episode of reform. The four propositions on which the dominant interpretation are based - the Commission as imperialistic, opportunistic, monolithic, and dominant - inform accounts of policy development and policy change more broadly in the literature. The experience of modernisation shows, however, that they can lead to a mistaken view of where reform originates, a misattribution of what motivates the Commission, an exaggeration of its power, and a failure to take account of the internal dynamics of Commission decision-making. It also illustrates how taking a materialistic, interest-based approach leads to a neglect of important factors that in some policy areas at least play an important part in influencing, constraining and guiding Commission action, pointing to the need for greater care in theorising EU policy reform. The modernisation of antitrust reform underlines the importance of the ideational, the institutional and the organisational. 


\section{Appendix}

Council Regulation (EC) No 1/2003 of 16 December 2002 on the implementation of the rules on competition laid down in Articles 81 and 82 of the Treaty, OJL 1, 04.01.2003, 1-25

Commission Regulation (EC) No 773/2004 of 7 April 2004 relating to the conduct of proceedings by the Commission pursuant to Articles 81 and 82 of the EC Treaty, OJ L 123, 27.04.2004, 18-24

Commission Notice on cooperation within the Network of Competition Authorities

OJ C 101, 27.04.2004, 43-53

Commission Notice on the co-operation between the Commission and the courts of the EU Member States in the application of Articles 81 and $82 \mathrm{EC}$ OJ C 101, 27.04.2004, 54-64

Commission Notice on the handling of complaints by the Commission under Articles 81 and 82 of the EC Treaty

OJ C 101, 27.04.2004, 65-77

Commission Notice on informal guidance relating to novel questions concerning Articles 81 and 82 of the EC Treaty that arise in individual cases (guidance letters)

OJ C 101, 27.04.2004, 78-80

Commission Notice - Guidelines on the effect on trade concept contained in Articles 81 and 82 of the Treaty

OJ C 101, 27.04.2004, 81-96

Communication from the Commission - Notice - Guidelines on the application of Article 81(3) of the Treaty

OJ C 101, 27.04.2004, 97-118 


\section{References}

Amato, G. (1997) Antitrust and the Bounds of Power, Oxford: Hart

Beach, D. (2003) 'Towards a new method of constitutional bargaining? The role and impact of EU institutions in the IGC and convention method of treaty reform', European Union Studies Association (EUSA) Biennial Conference 2003 (8th), March 27-29, Nashville, Tennessee

Bulmer, S. (1994) 'Institutions and Policy Change in the European Communities: the Case of Merger Control', Public Administration, 72, 423444

Cini, M. and McGowan, L. (1998) Competition Policy in the European Union, Basingstoke: Macmillan

Coen, D. and Thatcher, M. (2007) 'Network Governance and Delegation: European Networks of Regulatory Agencies', Regulation and Governance.

Cram, L. (1994) 'The European Commission as a MultiOrganization: Social Policy and IT Policy in the EU', Journal of European Public Policy, 1, 195217

Drahos, M. (2001) Convergence of Competition Laws and Policies in the European Community, Duventer: Kluwer

Dunleavy, P. (1991) Democracy, Bureaucracy and Public Choice, Brighton: HarvesterWheatsheaf

Egeberg, M. (2006) Multilevel Union Administration: Government in the Melting Pot, London: Palgrave

Ehlermann, C-D. (2000) 'The Modernization of EC Antitrust Policy: A Legal and Cultural Revolution', Common Market Law Review, 37, 537-574

European Commission (1999) White Paper on the Modernization of the Rules Implementing Articles 81 and 82 of the EC Treaty, Commission Programme No. 99/027, 28 April

Fingleton, J. (n.d.) 'Modernisation of the European Competition Rule', presentation to the IBA,

Gerber, D. (1998) Law and Competition in Twentieth Century Europe, Oxford: Clarendon Press

Gerber, D. (2001) 'Modernising European Competition Law: A Developmental Perspective', European Competition Law Review, 22, 122-130 
Goyder, D.G. (2003) EC Competition Law, $4^{\text {th }}$ edition, Oxford: Oxford University Press

Haas, P. (1992) 'Epistemic communities and international policy coordination', International Organization, 46, 1-35

Hix, S. $(1999,2005)$ The Political System of the European Union, $1^{\text {st }}$ edn, $2^{\text {nd }}$ edn, London: Palgrave,

Kassim, H. and Dimitrakopoulos, D.G. (2006) 'Leader or bystander? The European Commission and EU Treaty Reform' (with Dionyssis G.Dimitrakopoulos) in Derek Beach and Colette Mazzucelli (eds) Leadership in EU constitutional negotiations, Palgrave

Kassim, H. and Dimitrakopoulos, D.G. (2007) 'The European Commission and the future of Europe' in D.Beach and T.Christiansen (eds), 14(8), 1-22, special issue of Journal of European Public Policy

Kassim, H. and Stevens, H. (forthcoming 2008) The European Union and Air Transport: Europeanization and its Limits

Maher, I. (2005) 'Networking competition authorities in the European Union: Diversity and change', in C-D. Ehlermann and I. Atanasiu (eds), European Competition Law Annual 2002: Constructing the EU Network of Competition Authorities. Hart Publishing, Oxford. 223-226 and commentary 161-164.

Maher, I. (2002) 'Competition law in the international domain: Networks as a new form of governance,' Journal of Law and Society 29(1), 112-136. (Also reproduced in S. Picciotto and D. Campbell (eds) (2002), New Directions in Regulatory Theory. Blackwell, Oxford.)

Majone, G. (2001) 'Two logics of delegation: agency and fiduciary relations in EC governance', European Union Politics, 2, 103-222

McGowan, L. (2005) 'Europeanization unleashed and rebounding: assessing the modernization of EU cartel policy', Journal of European Public Policy, 12(6), 986-1004

Neven, D., Papandropoulos, P. and Seabright, P. (1998) Trawling for Minnows: European Competition Policy and Agreements between Firms, London: Centre for European Policy Research

Niskanen, W. (1971) Bureaucracy and Representative Government, Chicago: Aldine 
Pijetlovic, K. (2004) 'Reform of EC antitrust enforcement: criticism of the new system is highly exaggerated', European Competition Law Review, 25(6), 356-69

Riley, A. (2003a) 'EC Antitrust Modernisation: The Commission does very nicely - thank you! Part 1: Regulation 1 and the notification burden', E.C.L.R. 2003, 24(11), 604-615

Riley, A. (2003b) ‘EC Antitrust Modernisation: The Commission does very nicely - thank you! Part 2: Between the idea and the reality: decentralisation under Regulation 1, E.C.L.R. 2003, 24(11), 657-672

Schmidt, S. K. (2000) Only an Agenda Setter? The European Commission's Power over the Council of Ministers',

Simanska, B. (2005) 'The Antitrust enforcement in the enlarged EU: Linking effectiveness with uniformity', paper presented at EUSA biennial conference, 31 March-2 April, Austin

Swank, G.T. and Büthe, T. (2005) 'The Politics of Antitrust and Merger Review in the European Union: Institutional Change and Decisions from Messina to 2004', paper presented at EUSA biennial conference, 31 March-2 April, Austin

Van Waarden, F. and Drahos, M. (2002) 'Courts and (Epistemic) Communities in the Convergence of Competition Policy', Journal of European Public Policy, 9(6), 913-34

Venit, J. (2003) 'Brave New World: The Modernization and Centralization of Enforcement under Articles 81 and 82 of the EC Treaty', Common Market Law Review, 40, 545-580

Wilks, S. (1992) Models of European Administration: DG IV and the administration of competition policy, paper delivered at Conference of the European Group of Public Administration, Scuola Superiore di Studi universitari e di Perfezionamento, S. Anna, Pisa, Italy 2-5 September

Wilks, S. (2005a) 'Agency Escape: Decentralization or Dominance of the European commission in the Modernization of Competition Policy?' Governance, 8(3), 431-452

Wilks, S. (2005b) 'Competition Policy' in H. Wallace, W.Wallace and M.A. Pollack (eds) Policy Making in the European Union, Oxford: Oxford University Press 